\title{
The effect of inhibitors of methane production on fermentation pattern and stoichiometry in vitro using rumen contents from sheep given molasses
}

\author{
BY R. J. MARTY* AND D. I. DEMEYER \\ Faculty of Agricultural Sciences, University of Ghent, Belgium \\ (Received 1o fanuary 1973-Accepted 10 April 1973)
}

\begin{abstract}
r. The fermentation in the presence of four known methane inhibitors was investigated in rumen contents from sheep given molasses ad lib. and showing two different fermentation patterns.

2. The average hydrogen recoveries obtained with the high butyrate and high propionate patterns were $93 \pm 2$ and $95 \pm 2 \%$ respectively.

3. Sodium sulphite, chloral hydrate and a hemiacetal of chloral and starch (HCS) all inhibited methane production, and were associated with an accumulation of hydrogen and lactate in rumen contents showing the high butyrate fermentation pattern. Propionate production was slightly stimulated.

4. In rumen contents showing the high propionate fermentation pattern, linseed-oil hydrolysate depressed methane production at high levels only, increased hydrogen and lactate production but depressed all other products, and HCS depressed methane production and slightly increased propionate production.

5. Low hydrogen recoveries in the presence of the inhibitors were probably associated with the utilization of metabolic hydrogen in reactions not accounted for in the scheme under investigation.
\end{abstract}

Improvement in analytical techniques for the estimation of the end-products of rumen fermentation, together with increased understanding of metabolic pathways, has led to the development of theoretical schemes to describe the conversion of substrates into products such as volatile fatty acids (VFA), methane, hydrogen and incorporation into microbial cells (Wolin, 1960; Hungate, 1966; Baldwin, Lucas \& Cabrera, 1970; Hungate, Reichl \& Prins, 1971).

Demeyer, Henderickx \& Van Nevel (I972) have recently proposed a comprehensive scheme incorporating cell synthesis, which is based on a theoretical fermentation balance described by Wolin (1960). This has been tested using in vitro incubations with rumen contents taken from a sheep given hay and concentrates (Van Nevel, Demeyer \& Henderickx, I972). To enable conclusions on its general applicability, further experiments with rumen contents showing different fermentation patterns are necessary. Our investigation into the application of the scheme was done with rumen contents of sheep given molasses but presenting two different fermentation patterns, one high in butyrate, the other high in propionate. The effect of some known inhibitors of methane production (Czerkawski, I969; Marty, 1972) on the stoichiometry underlying the scheme was also investigated. However, as the amounts of end-products obtained with animals given molasses were different from those found by Van Nevel et al. (1972), the general equations were expanded to account for lactic acid and valeric acid as additional end-products of fermentation.

* Present address: Instituto de Ciencia Animal, University of Habana, Cuba. 
EXPERI MENTAL

Animals. Two wethers ( $\mathrm{B}$ and $\mathrm{C}$ ), individually penned and fitted with rumen fistulas, were given diets containing hay $(200 \mathrm{~g} / \mathrm{d}$ ) and molasses (composition, $\mathrm{g} / \mathrm{kg}$ ): molasses 900; fish meal 20; urea 20; $\mathrm{NaCl}_{5}$; vitamin and mineral mixture (Kowalczyk, Ramirez \& Geerken, I970) 5; water 50; ad lib. (an average of $2 \mathrm{~kg} / \mathrm{d}$ ). This molasses mixture had a dry-matter content of $665 \mathrm{~g} / \mathrm{kg}$. Two weeks before the experiments began, the fermentation pattern of sheep $\mathrm{C}$ was changed by infusing $\mathrm{I} \mathrm{kg}$ molasses in $15 \mathrm{~min}$ on 3 consecutive $d$. The expected change in microbial population due to the lowering of the $\mathrm{pH}$ would allow the testing of the scheme with two fermentation patterns (one high in butyrate, the other high in propionate) on the same type of diet. Both animals maintained their respective fermentation patterns and similar dry-matter intakes over the experimental period of ro weeks.

Incubations. Samples of rumen contents were withdrawn before the animals were given the hay, using the apparatus described by Hungate (I95). The samples were filtered through stainless-steel wire gauze ( $16 \mathrm{mesh}$ ) and $25 \mathrm{ml}$ filtrate were transferred anaerobically (continuous flushing with $\mathrm{CO}_{2}$ ) to an incubation flask containing $25 \mathrm{ml}$ buffer solution (pH 6.9) (Burroughs, Frank, Gerlaugh \& Bethke, 1950) and $5 \mathrm{mg}$ nitrogen in the form of $\mathrm{NH}_{4} \mathrm{HCO}_{3}$. All incubations were carricd out anaerobically (under $\mathrm{CO}_{2}$ ) for $3 \mathrm{~h}$ at $39^{\circ} \mathrm{C}$ in a water-bath fitted with a shaker. The evacuation technique of Umbreit, Burris \& Stauffer (I959) was used to fill the vessels with $\mathrm{CO}_{2}$. The substrate $(0.7 \mathrm{mmol}$ sucrose (AR grade, UCB, Brussels) $+0.2 \mathrm{mmol} \mathrm{D}(+)-$ glucose (bacteriological grade, Merck, Darmstadt) $+0 \cdot 1 \mathrm{mmol} \mathrm{D}(-)$-fructose (AR grade, Merck, Darmstadt)) was dissolved in $25 \mathrm{ml}$ Burroughs' buffer solution, the inhibitors were added, and the mixture was emulsified with a Bühler homogenizer (Virtis 45, Virtis Co., Gardiner, NY) (5000o rev./min; $30 \mathrm{sec})$. The four known inhibitors of methane production were sodium sulphite, chloral hydrate, linseed-oil hydrolysate (LOH), and a hemiacetal of chloral and starch (HCS) (LOH was a generous gift from Oléochim N.V. Brussels, and HCS from Smith, Kline \& French Laboratories, Philadelphia, Pennsylvania). Incubation flasks were fitted with a silicone rubber septum to permit gas sampling with a Hamilton gas-tight syringe (Micromesure, N.V., The Hague). Incubations were stopped by the injection of I $\mathrm{ml} \mathrm{H}_{3} \mathrm{PO}_{4}$ (AR grade, Merck, Darmstadt).

Analytical techniques. Methane and hydrogen contents were determined by gassolid adsorption chromatography (Demeyer \& Henderickx, 1967), and total and individual VFA by gas-liquid chromatography (Cottyn \& Boucqué, I968). Lactic acid production was determined by the microdiffusion method described by Conway (1957).

Calculation of fermentation balance. The amounts of acetic $(A)$, propionic $(P)$, butyric $(B)$, valeric $(V)$ and lactic $(L)$ acids produced were obtained by subtracting the amounts present initially in the rumen contents from those determined at the end of the incubation period. From these values, the theoretical amount of hexose $\left(\mathrm{C}_{6}\right)$ metabolized was calculated as

$$
\mathrm{C}_{6}=\frac{1}{2} A+\frac{1}{2} P+B+V+\frac{1}{2} L
$$


(Wolin, 1960). As comparison of fermentation patterns requires correction for differences in rate of fermentation, production of acids, $\mathrm{CH}_{4}$ and $\mathrm{H}_{2}$ were expressed as $\mu \mathrm{mol} / \mathrm{mmol} \mathrm{C}_{6}$ metabolized. From these values metabolic hydrogen $(2 \mathrm{H})$ produced and recovered was calculated as follows:

$2 \mathrm{H}$ recovered:

$$
\text { total } 2 \mathrm{H} \text { produced }=2 A+P+{ }_{4} B+{ }_{3} V,
$$

$$
\begin{aligned}
& \text { in end-products }=2 P+2 B+4 V+{ }_{4} \mathrm{CH}_{4}+\mathrm{H}_{2}, \\
& \text { in cells }=\left(A+P+B+V+\frac{1}{2} L\right) \times 30 \times 0.006 \mathrm{I} .
\end{aligned}
$$

The total amount of hydrogen recovered was expressed as a percentage of hydrogen produced. The equations on which these calculations are based were reported in earlier work (Wolin, 1960; Demeyer \& Henderickx, r967; Demeyer, Van Nevel, Henderickx \& Martin, I970; Demeyer, Henderickx \& Van Nevel, I972; Van Nevel et al. 1972). As significant amounts of lactic acid and valeric acid were regularly detected, the formation of these end-products was incorporated into the scheme, based on the equations:

$$
\begin{gathered}
\mathrm{C}_{6} \mathrm{H}_{12} \mathrm{O}_{6}-{ }_{2} \mathrm{CH}_{3} \mathrm{CHOHCOOH}, \\
\mathrm{CH}_{3} \mathrm{CH}_{2} \mathrm{COOH}+\mathrm{CH}_{3} \mathrm{COOH}+4 \mathrm{H}-\mathrm{CH}_{3}\left(\mathrm{CH}_{2}\right)_{3} \mathrm{COOH}+{ }_{2} \mathrm{H}_{2} \mathrm{O} .
\end{gathered}
$$

It was assumed that $30 \mathrm{~g}$ cellular dry matter were formed/mol VFA (Baldwin, 1970; Van Nevel et al. 1972), requiring 30 $\times 0.006 \mathrm{r} \mathrm{mol} \mathrm{2H} \mathrm{(Demeyer,} \mathrm{Henderickx} \mathrm{\&} \mathrm{Van}$ Nevel, I972). The cellular dry-matter yield/mol lactic acid was assumed to be half the yield/mol VFA, because according to the Embden-Meyerhof pathway, only I mol ATP/mol lactic acid is produced, whereas 2 mol ATP are gained for each mol VFA produced (Walker, r968).

\section{RESULTS}

Differences in the fermentation pattern of the rumen contents from the two sheep were reflected in the VFA composition (Table I). Sheep B maintained a higher production of butyrate than propionate which was typical for animals given molasses (Marty \& Preston, I970); this situation was reversed in sheep C.

This reversal was even more apparent in the end-products of fermentation obtained in incubations without inhibitors; total VFA, acetate and propionate production/ mmol $\mathrm{C}_{6}$ fermented were significantly higher, and production of methane, hydrogen and butyrate were significantly lower in rumen contents of sheep C (Table 2).

Methane production for the two sheep was inversely related to propionate production and acetate production was inversely related to butyrate production (Fig. I). Average hydrogen recovery was approximately $95 \%$ in both experiments.

The effect of inhibitors on the fermentation pattern is shown in Table 3 for Expt 3 (rumen contents from sheep B) and in Table 4 for Expt 4 (rumen contents from sheep C).

All inhibitors, at the concentrations used, considerably reduced or completely inhibited methane production in vitro in rumen contents from sheep $B$ and this was 
Table I. Amounts of lactic acid and volatile fatty acids (VFA), and molar proportions of $V F A$ in sheep $B$ and $C$ with high butyrate and high propionate fermentation patterns respectively

(Mean values with their standard errors for ten determinations)

\begin{tabular}{|c|c|c|c|c|c|c|c|c|c|c|c|c|}
\hline \multirow[b]{3}{*}{ Animal } & \multirow{2}{*}{\multicolumn{2}{|c|}{$\begin{array}{c}\text { Lactic acid } \\
\text { (mmol/l) }\end{array}$}} & \multirow{2}{*}{\multicolumn{2}{|c|}{$\begin{array}{c}\text { Total VFA } \\
(\mathrm{mmol} / \mathrm{l})\end{array}$}} & \multicolumn{8}{|c|}{ Molar proportions of VFA (\%) } \\
\hline & & & & & $\mathrm{Ac}$ & & Prop & nic & But & & Val & ric \\
\hline & Mean & $\mathrm{SE}$ & Mean & $\mathrm{SE}$ & Mean & SE & Mean & $\mathrm{SE}$ & Mean & $\mathrm{SE}$ & Mean & SE \\
\hline Sheep B & 0.456 & 0.028 & $37 \cdot 44$ & $6 \cdot 12$ & 69.9 & $2 \cdot I$ & $12 \cdot 6$ & 0.7 & $\mathrm{I}_{4} \cdot 8$ & $2 \cdot 5$ & $2 \cdot 7$ & 0.6 \\
\hline Sheep C & 0.568 & 0.032 & $44 \cdot 57$ & $4 \cdot 57$ & $66 \cdot 6$ & $2 \cdot 1$ & $20 \cdot 3$ & $2 \cdot 9$ & 10.7 & 0.9 & $2 \cdot I$ & 0.4 \\
\hline
\end{tabular}

Table 2. Effect of high butyrate and high propionate fermentation pattern of sheep $B$ and $C$, respectively, on the fermentation balance and end-products of in vitro incubations of rumen contents with sugars ( $\mathrm{I} 700 \mathrm{\mu mol}$ hexose)

(Mean values with their standard errors for ten incubations)

\begin{tabular}{|c|c|c|c|c|}
\hline & \multicolumn{2}{|c|}{ Expt I (sheep B) } & \multicolumn{2}{|c|}{ Expt 2 (sheep C) } \\
\hline & Mean & $\mathbf{S E}$ & Mean & $\mathrm{SE}$ \\
\hline Hexose theoretically metabolized $(\mu \mathrm{mol})$ & II 57.0 & $16 \cdot 42$ & III $3 \cdot I$ & 30.42 \\
\hline \multicolumn{5}{|c|}{ End-products formed* } \\
\hline Lactic acid & $7 \cdot 6$ & $r \cdot 3$ & $8 \cdot 1$ & 0.5 \\
\hline Methane & $359 \cdot 3$ & 13.2 & $224 \cdot 5$ & $30 \cdot 3$ \\
\hline Hydrogen & $17 \cdot 3$ & $3 \cdot I$ & $5 \cdot 3$ & $1 \cdot 4$ \\
\hline Total VFA & I $200 \cdot 9$ & $23 \cdot 2$ & 1674.7 & $45 \cdot 4$ \\
\hline Acetic acid & $290 \cdot 1$ & $43^{\cdot} \mathrm{I}$ & $722 \cdot 8$ & $35 \cdot 6$ \\
\hline Propionic acid & $\operatorname{II9.4}$ & $9 \cdot 8$ & $633^{\cdot 6}$ & $8 x \cdot 7$ \\
\hline Butyric acid & $759^{\circ} 9$ & 20.9 & 297.0 & $44 \cdot 2$ \\
\hline Valeric acid & $31 \cdot 3$ & $5 \cdot 7$ & $2+1 \cdot 2$ & $4 \cdot 2$ \\
\hline Hydrogen recovery $(\%)$ & $92 \cdot 63$ & $\mathrm{I} \cdot 54$ & $94 \cdot 70$ & $2 \cdot 04$ \\
\hline
\end{tabular}

VFA, volatile fatty acids.

* All end-products are expressed in $\mu \mathrm{mol} / \mathrm{mmol}$ hexose theoretically metabolized, calculated from the end-products, after subtracting the initial contents of $\mathrm{VFA}$ and lactic acid in $25 \mathrm{ml}$ strained rumen contents.

accompanied by a considerable increase in hydrogen and lactate production. Propionate production was slightly stimulated and the amount of substrate fermented, as calculated from VFA and lactate production was slightly depressed. Hydrogen recovery dropped to an average of $85 \%$ in the presence of inhibitors; the lowest recovery was obtained with the highest concentration of sodium sulphite.

With rumen contents from sheep $\mathrm{C}$ only very high levels of $\mathrm{LOH}$ depressed methane production, resulting in an increase in lactate and hydrogen production, and a depression in the amounts of other products. Hydrogen recovery was the lowest measured. HCS again completely depressed methane production, but there was neither a depression in the production of VFA nor an accumulation of hydrogen nor lactic acid; propionate production was, however, increased. 

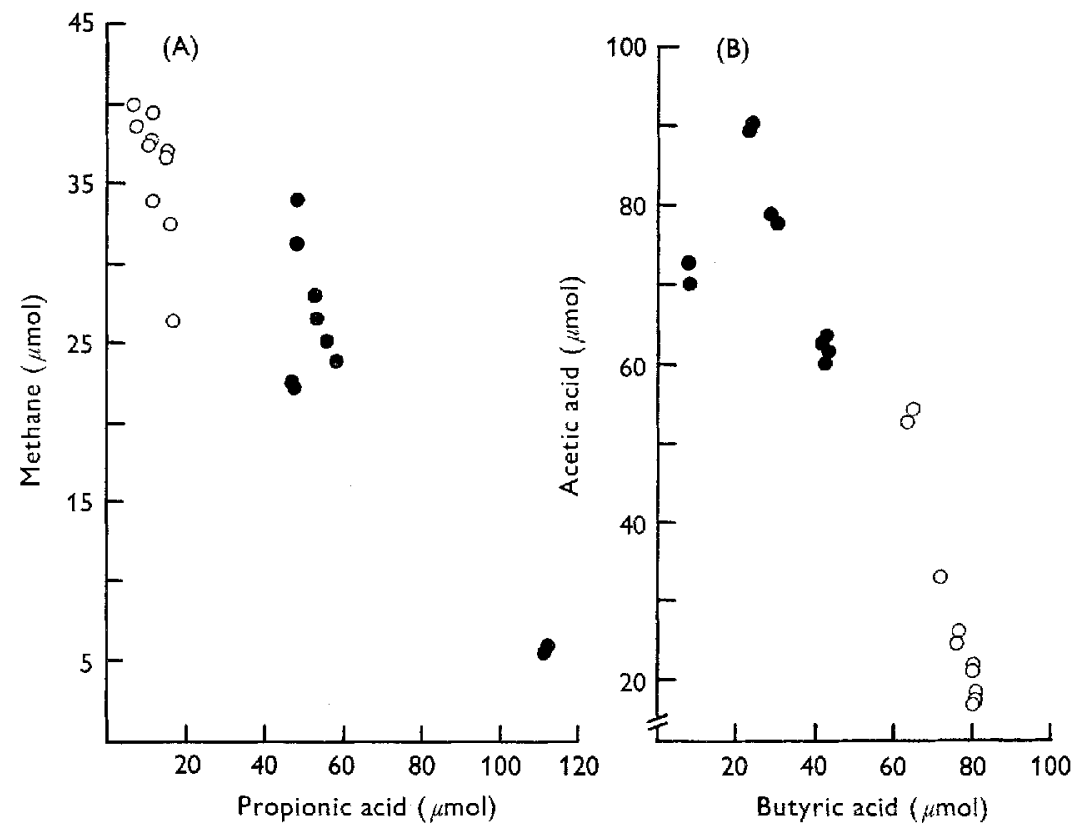

Fig. I. Inverse relationship between methane and propionate production $(A)$ and acetate and butyrate production $(B)$, in vitro, in rumen contents from sheep $B$ and $C$ with high butyrate and high propionate fermentation patterns respectively. $\mathrm{O}$, Expt I;, Expt 2.

Table 3. Expt 3. Effect of inhibitors on the fermentation balance and end-products of in vitro incubations of sugars with rumen contents from sheep $B$

\begin{tabular}{|c|c|c|c|c|c|c|c|c|c|c|}
\hline \multirow[b]{2}{*}{$\begin{array}{l}\text { Compounds } \\
\text { tested }\end{array}$} & \multicolumn{8}{|c|}{ End-products formed ( $\mu \mathrm{mol} / \mathrm{mmol}$ hexose metabolized)* } & \multirow{2}{*}{$\begin{array}{c}\text { Hexose } \\
\text { fer- } \\
\text { mented } \\
(\mu \mathrm{mol})\end{array}$} & \multirow{2}{*}{$\begin{array}{c}2 \mathrm{H} \dagger \\
\text { re- } \\
\text { covery } \\
(\%)\end{array}$} \\
\hline & $\begin{array}{l}\text { Lactic } \\
\text { acid }\end{array}$ & $\begin{array}{l}\text { Me- } \\
\text { thane }\end{array}$ & $\begin{array}{c}\text { Hydro- } \\
\text { gen }\end{array}$ & $\begin{array}{l}\text { Total } \\
\text { VFA }\end{array}$ & Acetic & $\begin{array}{l}\text { Pro- } \\
\text { pionic }\end{array}$ & Butyric & Valcric & & \\
\hline \multicolumn{11}{|c|}{ Sodium sulphite: } \\
\hline Control & 10 & 384 & 29 & I I 54 & 214 & 104 & 808 & 28 & I 122 & $96 \cdot 8$ \\
\hline $4 \mathrm{mmol} / 1$ & $5^{8}$ & 69 & 737 & 1099 & 142 & 114 & 816 & 26 & 1107 & $84 \cdot 9$ \\
\hline Control & 5 & 368 & 14 & I 334 & 533 & I 39 & 645 & I6 & I20I & $87 \cdot 5$ \\
\hline $8 \mathrm{mmol} / 1$ & 223 & I & 799 & 1099 & 280 & $14 I$ & 670 & 8 & 1059 & $78 \cdot 4$ \\
\hline \multicolumn{11}{|c|}{ Chloral hydrate: } \\
\hline Control & 8 & $36 r$ & 9 & I 185 & $25^{6}$ & I 2 I & 762 & 46 & II 22 & $94 \cdot 6$ \\
\hline $2 \mathrm{mmol} / \mathrm{l}$ & 283 & 0 & $74 I$ & 929 & 7 & 135 & 763 & 25 & 976 & $86 \cdot 3$ \\
\hline Control & 4 & 391 & 28 & 1163 & 257 & 73 & 777 & 56 & 1123 & $96 \cdot 4$ \\
\hline Io $\mathrm{mmol} / \mathrm{I}$ & 495 & 0 & 796 & 840 & IOI & 73 & 627 & 38 & 987 & $87 \cdot 7$ \\
\hline \multicolumn{11}{|c|}{ Hemiacetal of chloral and starch: } \\
\hline Control & I I & 292 & 7 & I 169 & 190 & I 59 & 808 & 12 & I2I 7 & $88 \cdot 3$ \\
\hline $0.6 \mathrm{mmol} / 1$ & 35 & 49 & 5 I6 & 1092 & 26 & 194 & 857 & I 6 & 999 & $82 \cdot 6$ \\
\hline $\mathrm{I} \cdot 2 \mathrm{mmol} / \mathrm{I}$ & 48 & 14 & 628 & 1068 & -26 & 210 & 869 & 15 & 914 & $84 \cdot I$ \\
\hline
\end{tabular}

VFA, volatile fatty acids.

* Calculated from the end-products, after subtraction of values for initial content of VFA and lactic acid in $25 \mathrm{ml}$ strained rumen contents. Values are the average of four incubations.

$\uparrow$ Metabolic hydrogen. 
Table 4. Expt 4. Effect of inhibitors on the fermentation balance and end-products of in vitro incubations of sugars with rumen contents from sheep $C$

\begin{tabular}{|c|c|c|c|c|c|c|c|c|c|c|}
\hline \multirow[b]{2}{*}{$\begin{array}{l}\text { Compounds } \\
\text { tested }\end{array}$} & \multicolumn{8}{|c|}{ End-products formed ( $\mu \mathrm{mol} / \mathrm{mmol}$ hexose metabolized)* } & \multirow{2}{*}{$\begin{array}{c}\text { Hexose } \\
\text { fer- } \\
\text { mented } \\
(\mu \text { mol })\end{array}$} & \multirow{2}{*}{$\begin{array}{c}2 \mathrm{H}+ \\
\text { re- } \\
\text { covery } \\
(\%)\end{array}$} \\
\hline & $\begin{array}{c}\text { Lactic } \\
\text { acid }\end{array}$ & $\begin{array}{l}\text { Me- } \\
\text { thane }\end{array}$ & $\begin{array}{l}\text { Hydro- } \\
\text { gen }\end{array}$ & $\begin{array}{l}\text { Total } \\
\text { VFA }\end{array}$ & Acetic & $\begin{array}{l}\text { Pro- } \\
\text { pionic }\end{array}$ & Butyric & Valeric & & \\
\hline \multicolumn{11}{|c|}{ Linseed-oil hydrolysate: } \\
\hline Control & 7 & 326 & I4 & I 549 & 622 & 476 & 425 & 23 & 1000 & $99 \cdot 9$ \\
\hline $2 \mathrm{mmol} / 1$ & $2 \mathrm{I}$ & 290 & 24 & 1478 & 552 & 426 & 468 & 34 & I 179 & $96 \cdot 2$ \\
\hline Control & 7 & 224 & 5 & I 534 & 608 & 467 & 440 & I 8 & I 190 & $87 \cdot 1$ \\
\hline Io $\mathrm{mmol} / \mathrm{l}$ & 1049 & 29 & $\mathrm{I} 8_{3}$ & 732 & 344 & 168 & 235 & $-\mathrm{I}_{4}$ & 1033 & $72 \cdot 5$ \\
\hline \multicolumn{11}{|c|}{ Hemiacetal of chloral and starch: } \\
\hline Control & I I & 57 & I & I 9I I & 714 & I I I 8 & 79 & $-I$ & 1025 & 103.5 \\
\hline $3 \mathrm{mmol} / 1$ & 8 & 0 & 2 & 1929 & 701 & I I 56 & 70 & -2 & 971 & \\
\hline $6 \mathrm{mmol} / 1$ & 8 & 0 & $\mathbf{I}$ & 1920 & 707 & I I $4 x$ & 74 & -2 & 990 & $97^{\prime 2}$ \\
\hline
\end{tabular}

VFA, volatile fatty acids.

* Calculated from the end-products, after subtraction of values for initial content of VFA and lactic acid in $25 \mathrm{ml}$ strained rumen contents. Values are the average of four incubations.

$\dagger$ Metabolic hydrogen.

Table 5. Effect of fermentation pattern on calculated hydrogen recovery for different in vitro incubations of hexoses with rumen contents from sheep

(Mean values with their standard errors)

\begin{tabular}{|c|c|c|c|c|c|c|c|c|c|c|c|}
\hline \multirow[b]{3}{*}{ Substrate } & \multirow[b]{3}{*}{ Expt } & \multicolumn{8}{|c|}{ ( $\mu \mathrm{mol} / \mathrm{mmol}$ hexose metabolized) } & \multirow{2}{*}{\multicolumn{2}{|c|}{$\begin{array}{c}\begin{array}{c}2 \mathrm{H} \mathbf{I}^{*} \text { re- } \\
\text { covery } \\
(\%)\end{array} \\
\overbrace{}^{(\%)}\end{array}$}} \\
\hline & & \multicolumn{2}{|c|}{$\overbrace{}^{\text {Acetate }}$} & \multicolumn{2}{|c|}{ Propionate } & \multicolumn{2}{|c|}{ Butyrate } & \multicolumn{2}{|c|}{ Methane } & & \\
\hline & & Mean & SE & Mean & $\mathrm{SE}$ & Mean & $\mathrm{SE}$ & Mean & $\mathrm{SE}$ & Mean & $\mathrm{SE}$ \\
\hline Glucose & $\begin{array}{l}\text { Van Nevel } \\
\text { et } a I .(1972\end{array}$ & 1250 & 30 & $43^{\circ}$ & 50 & 160 & 20 & 530 & 40 & 102 & 4 \\
\hline \multirow[t]{2}{*}{$\begin{array}{l}\text { Glucose }+ \\
\text { fructose }+s\end{array}$} & $\begin{array}{l}\text { Expt I } \\
\text { crose }\end{array}$ & 290 & $4^{\circ}$ & r20 & Io & 760 & 20 & 360 & 10 & 93 & 2 \\
\hline & Expt 2 & 730 & 40 & 630 & 80 & 300 & 40 & 220 & 30 & 95 & 2 \\
\hline
\end{tabular}

\section{DISCUSSION}

The high values for hydrogen recovery in incubations without inhibitors were additional evidence for the validity of the fermentation balance scheme proposed by Demeyer, Henderickx \& Van Nevel (I972), as they accounted for most of the endproducts of carbohydrate metabolism. Hydrogen recoveries close to $100 \%$ were reported, with the same scheme, for in vitro fermentation of various sugars (Van Nevel et al. 1972), and in vitro fermentation of glucose in the presence of oxygen (Demeyer, Van Nevel \& Henderson, I972). In these earlier experiments the rumen contents of the animal, given hay and concentrates, had a high acetate fermentation pattern. In our investigation the scheme was tested with rumen contents showing a high butyrate or a high propionate fermentation pattern (Table 5). Furthermore, a high butyrate or high propionate fermentation pattern was established using the same substrate, but different sources of rumen contents. In this respect, our results 
are similar to those described by O'Connor, Myers, Maplesden \& Vander Noot (1971).

The production of total VFA in Expt $2(1670 \mu \mathrm{mol} / \mathrm{mmol} \mathrm{C}$ ) was similar to the value reported by Van Nevel et al. (1972) (1870 $\mu \mathrm{mol} / \mathrm{mmol} \mathrm{C}_{6}$ ) and that calculated from results presented by Czerkawski \& Breckenridge (1969) ( $1780 \mu \mathrm{mol} / \mathrm{mmol} \mathrm{C}_{6}$ ). In Expt I the value was lower ( $1200 \mu \mathrm{mol} / \mathrm{mmol} \mathrm{C}_{6}$ ). The production of I mol butyrate requires I mol hexose, whereas the production of acetate or propionate requires $0.5 \mathrm{~mol}$ hexose. Since in these experiments the butyrate production was high one would expect low total VFA production per mol hexose. For methane production, our values of 220 and $360 \mu \mathrm{mol} \mathrm{CH} / \mathrm{mmol} \mathrm{C}_{6}$ were lower than those of Czerkawski \& Breckenridge (1969) (550 $\mu \mathrm{mol})$ and of Van Nevel et al. (1972) (430 $\mu \mathrm{mol})$, and were related to higher proportions of propionate and butyrate respectively. Furthermore, an inverse relationship between propionate and methane production was again apparent when results for the two experiments were pooled, although this relationship was not apparent from individual results from each experiment, where it was affected by variations in butyrate production and in the amount of metabolic hydrogen recovered (Van Nevel et al. 1972).

The inhibitory activity of the compounds tested merits little comment, as the results are similar to those reported by other workers, under different experimental conditions (Czerkawski, Blaxter \& Wainman, I966; Krabill, Alhassan \& Satter, 1969; Van Nevel, Henderickx, Demeyer \& Martin, I969; Van Nevel, Demeyer \& Henderickx, I971; Trei, Scott \& Parish, 1972). With most compounds, however, a less pronounced effect on propionate production was observed than could be expected from results obtained with animals given hay and concentrates (Demeyer, Van Nevel, Henderickx $\&$ Martin, 1969). Only HCS gave a consistent increase in propionate production, together with an inhibition of methane production.

It is interesting that there were lower calculated hydrogen recoveries in the presence of the inhibitors, as it indicates that metabolic hydrogen was used in reactions not accounted for by the scheme. Sodium sulphite $(8 \mathrm{mmol} / \mathrm{l})$ decreased the recovery to $78.4 \%$ and $10 \mathrm{mmol} / \mathrm{LOH}$ decreased it to $72.5 \%$. Both compounds can be reduced in the rumen (Lewis, 1954; Wilde \& Dawson, 1966), which could account for the lower recoveries. Indeed, complete reduction of both compounds would require about $\mathrm{r} \cdot 2$ and $\mathrm{r} \cdot 0 \mathrm{mmol} 2 \mathrm{H}$ respectively and the actual amounts missing in the balance are approximately 0.9 and $0.6 \mathrm{mmol}$ respectively. Furthermore, the accumulation of hydrogen, when methane production is inhibited, may induce its utilization in reactions not accounted for in the calculations. Low recoveries and accumulation of hydrogen were observed using chloral hydrate and HCS with rumen contents of sheep $B$ (Table 3). These are not reduced in the rumen like sulphite or $\mathrm{LOH}$ and thus could not account for the missing hydrogen. On the other hand, using HCS with rumen contents from sheep $\mathrm{C}$ resulted in high recoveries and no accumulation of hydrogen was observed (Table 4).

The authors thank C. Vermander and N. Faquaet for technical assistance. This work was done while R. J. M. held a scholarship from the Office of Cooperation for 
Development (OCD), Belgium, and was part of a thesis submitted for the degree of Doctor in Agricultural Sciences to the University of Ghent, Belgium.

\section{REFERENCES}

Baldwin, R. L. (1970). Am. J. clin. Nutr. 23, I 508.

Baldwin, R. L., Lucas, H. L. \& Cabrera, R. (1970). In Physiology of Digestion and Metabolism in the Ruminant p. 319 [A. T. Phillipson, editor]. Newcastle upon Tyne: Oriel Press.

Burroughs, W., Frank, N. A., Gerlaugh, P. \& Bethke, R. M. (1950). F. Nutr. 40, 9.

Conway, E. J. (1957). Microdiffusion Analysis and Volumetric Error p. 277. London: Crosby, Lockwood and Son Ltd.

Cottyn, B. G. \& Boucqué, Ch. V. (1968). F. agric. Fd Chem. I6, ro5.

Czerkawski, J. W. (1969). Wld Rev. Nutr. Diet. 11, 24.0.

Czerkawski, J. W., Blaxter, K. L. \& Wainman, F. W. (1966). Br. F. Nutr. 20, 349.

Czerkawski, J. W. \& Breckenridge, G. (I969). Br. F. Nutr. 23, 925.

Demeyer, D. I. \& Henderickx, H. K. (1967). Biochim. Biophys. Acta 137, 484 .

Demeyer, D. I., Henderickx, H. K. \& Van Nevel, C. J. (I972). Proc. Nutr. Soc. 31, 54A.

Demeyer, D. I., Van Nevel, C. J., Henderickx, H. K. \& Martin, J. (I969). In Energy Metabolism of Farm Animals p. I39 [K. L. Blaxter, J. Kielanowski and G. Thorbek, editors]. Newcastle upon Tyne: Oriel Press.

Demeyer, D. I., Van Nevel, C. J., Henderickx, H. K. \& Martin, J. (1970). In Energy Metabolism of Farm Animals p. 37 [A. Schürch and C. Wenk, editors]. Zurich: Juris Druck u. Verlag.

Demeyer, D. I., Van Nevel, C. J. \& Henderson, C. (1972). Proceedings of the Second World Congress on Animal Feeding. Madrid Vol, 5, p. 33.

Hungate, R. E. (1950). Bact. Rev. 14, I.

Hungate, R. E. (1966). The Rumen and its Microbes p. 269. London: Academic Press Ltd.

Hungate, R. E., Reichl, J. \& Prins, R. (I97I). Appl. Microbiol. 22, I I04.

Kowalczyk, J., Ramirez, A. \& Geerken, C. M. (1970). Revta cub. Cienc. agric. 4, I87.

Krabill, L. F., Alhassan, W. S. \& Satter, L. D. (1969). F. Dairy Sci. 52, r81z.

Lewis, D. (1954). Biochem. 7. 56, 391.

Marty, R. J. (1972). Revta cub. Cienc. agric. 6, 153.

Marty, R. J. \& Preston, T. R. (1970). Revta cub. Cienc. agric. 4, I 83 .

O'Connor, J. J., Myers, G. S. Jr, Maplesden, D. C. \& Vander Noot, G. W. (r97r). J. Anim. Sci. 32, 994.

Trei, J. E., Scott, G. C. \& Parish, R. C. (1972). 7. Anim. Sci. 34, 510.

Umbreit, W. W., Burris, R. H. \& Stauffer, J. F. (1959). Manometric Techniques p. 70. Minneapolis: Burgess Publishing Co.

Van Nevel, C. J., Demeyer, D. I. \& Henderickx, H. K. (r97r). Appl. Microbiol. 21, 365.

Van Nevel, C. J., Demeycr, D. I. \& Henderickx, H. K. (I972). Proceedings of the Second World Congress on Animal Feeding. Madrid Vol. 5, p. 27.

Van Nevel, C. J., Henderickx, H. K., Demeyer, D. I. \& Martin, J. ( I969). Appl. Microbiol. $17,695$.

Walker, D. J. (1968). Appl. Microbiol. r6, 1672.

Wilde, P. F. \& Dawson, R. M. C. (I 966). Biochem. f. 98, 469 .

Wolin, M. J. (1960). 7. Dairy Sci. 43, 1452. 